DOI: https://doi.org/10.32836/2521-666X/2019-2-64-15

УДК 339.923.061.1

\title{
Бусарєв Д.В.
}

кандидат економічних наук, ДННУ «Академія фрінансового управління»

\section{Busariev Dmytro}

State Educational-Scientific Institution «Academy of Financial Management»

\section{ВИЗНАЧЕННЯ ОСНОВНИХ ПРИНЦИПІВ ТА ФУНКЦІЙ СИСТЕМИ ЕКОНОМІЧНОЇ БЕЗПЕКИ ПАЛИВНО-ЕНЕРГЕТИЧНОГО КОМПЛЕКСУ \\ DETERMINATION OF THE BASIC PRINCIPLES AND FUNCTIONS OF THE SYSTEM OF ECONOMIC SECURITY OF THE FUEL AND ENERGY COMPLEX}

У статті визначено основні приниипи і функиії системи економічної безпеки паливно-енергетичного комплексу. Враховуючи той факт, що кожна сочіально-економічна система, яка входить до складу даного комплексу, повинна дотримуватися певного переліку принципів, необхідно викреслити і спеціальні принципи, дотримання яких із боку держави й інших власників призведе до забезпечення економічної безпеки иілого комплексу. Такими принципами є: принщип централізованого керівниџтва; принцип комплексного застосування ресурсів; принцип зворотного зв 'язку; принщип комплексної адаптивності; принцип дотримання балансу. За результатами проведеного дослідження виділено такі функиї системи економічної безпеки паливно-енергетичного комплексу: функиія державного контролю, захисна, контролююча, навчально-мотиваційна, обліково-аналітична, функція виявлення та попередження загроз і небезпек, наслідкова.

Ключові слова: безпека, економічна безпека, паливно-енергетичний комплекс, система економічної безпеки, принципи, функції.

В статье определены основные приниипы и функиии системы экономической безопасности топливно-энергетического комплекса. Учитывая тот факт, что каждая сочиально-экономическая система, которая входит в состав данного комплекса, должна придерживаться определенного перечня приниипов, необходимо вычеркнуть и специальные принципы, соблюдение которых со стороны государства и других собственников приведет к обеспечению экономической безопасности целого комплекса. Такими принципами являются: принцип централизованного управления; принщип комплексного применения ресурсов; принцип обратной связи; принщип комплексной адаптивности; принцип соблюдения баланса. 
По результатам проведенного исследования выделены следующие функции системы экономической безопасности топливно-энергетического комплекса: функиия государственного контроля, защитная, контролирующая, учебно-мотивационная, учетно-аналитическая, функиия обнаружения и предотвращения угроз и опасностей, следственная.

Ключевые слова: безопасность, экономическая безопасность, топливно-энергетический комплекс, система экономической безопасности, принцииы, функции.

The article defines the basic principles and functions of the system of economic security of the fuel and energy complex. The fuel and energy complex of Ukraine through political and economic instability is very sensitive to any external and internal threats. In order to adapt and counteract them, an effective system of economic security is needed. To do this, it is not enough to simply integrate the already existing systems of economic security, since the specifics of functioning require a new approach that would take into account the structural features of a complex socio-economic system, which is the fuel and energy complex. The formation of a new system of economic security for the fuel and energy complex is impossible without determining the basic principles and functions. The economic security system of a complex socio-economic system (for example, the fuel and energy complex) should be understood as a set of structural interconnected and interacting elements that are aimed at recognizing calls, minimizing risks, counteracting (adapting) external and internal threats and hazards, in order to achieve social economic and energy security. Considering the fact that each socio-economic system that is part of this complex must adhere to a specific list of principles, it is necessary to cross out special principles, compliance with the state and other owners will lead to ensuring the economic security of the whole complex. These principles are: the principle of centralized management; principle of integrated use of resources; feedback principle; principle of complex adaptability; principle of balance. According to the results of our study, we identify the following functions of the economic security system of the fuel and energy complex: the function of state control; protective, controlling, educational and motivational, accounting and analytical function of detecting and preventing threats and dangers, investigative. Economic security in the context of complex socio-economic systems requires the creation of such a system that will allow to coordinate interests not only within this complex system, but also with a higher level, that is, the state. If this is viewed in the context of this type of complex system, as a fuel and energy complex, then not only the achievement of economic interests, but also social and environmental ones should be in the foreground, taking into account the specifics of the activity.

Key words: security, economic security, fuel and energy complex, system of economic security, principles, functions.

Постановка проблеми. Паливно-енергетичний комплекс України через політико-економічну нестабільність є дуже чутливим до будь-яких зовнішніх і внутрішніх загроз. Для того щоб адаптуватися і протидіяти їм, необхідна ефективна система економічної безпеки. Для цього недостатньо просто інтегрувати наявні системи економічної безпеки, оскільки специфіка функціонування потребує нового підходу, який би врахував структурні особливості складної соціально-економічної системи, якою є паливно-енергетичний комплекс. Формування нової системи економічної безпеки для паливно-енергетичного комплексу неможливе без визначення основних принципів і функцій.

Аналіз останній досліджень і публікацій. Дослідженням проблем формування системи економічної безпеки соціально-економічної системи займалася значна кількість науковців, зокрема: Т. Іванюта, А. Заїчковський, Н. Зачосова, І. Мігус, О. Кириченко, В. Алькема, Н. Кирич, Ю. Вовк, О. Ляшенко, П. Пригунов, С. Кавун, О. Силкін, А. Штангрет, В. Ярочкін та ін.

Незважаючи на внесок кожного $з$ представлених нами науковців, на жаль, досі залишається актуальною і не розкритою в повному обсязі проблема формування системи економічної безпеки складної соціально-економічної системи, зокрема паливно-енергетичного комплексу.

Мета статті полягає у визначенні основних принципів та функцій системи економічної безпеки паливно-енергетичного комплексу.

Виклад основного матеріалу. Складні соціально-економічні системи суттєво впливають на стан національної економіки i мають характерні відмінності в структурі, 
які не притаманні іншим системам. Однією 3 таких є їхня «двобічність»: з одного боку, ми маємо відкритого виду систему, а з іншого практично повну підпорядкованість у функціонуванні і розвитку, яку здійснює система вищого порядку. Для формування системи економічної безпеки паливно-енергетичного комплексу необхідно врахувати цілу низку інтересів, починаючи від кожної окремо взятої соціально-економічної системи і закінчуючи державою у цілому.

Під системою економічної безпеки складної соціально-економічної системи (на прикладі паливно-енергетичного комплексу) слід розуміти сукупність структурних взаємозалежних та взаємодіючих елементів, які спрямовані на розпізнавання викликів, мінімізацію ризиків, протидію (адаптацію) зовнішнім і внутрішнім загрозам та небезпекам для досягнення соціальної, економічної та енергетичної безпеки.

Для складної соціально-економічної системи, до якої належить паливно-енергетичний комплекс, цілі слід розглядати як стратегічні, проміжні та оперативні.

Стратегічні цілі системи економічної безпеки складної соціально-економічної системи передбачають вирішення великих, масштабних проблем, які перешкоджають досягненню поставленої мети.

Проміжними цілями щодо стратегічних $\epsilon$ тактичні, які спрямовані на вирішення окремо взятих проблем, що сприятиме досягненню як стратегічних цілей, так і мети у цілому.

Оперативні цілі системи економічної безпеки складної соціально-економічної системи - це ті цілі, які ставляться і вирішуються кожного дня для забезпечення захищеності та досягнення тактичних цілей відповідно.

Слід зауважити, що всі цілі тісно взаємопов'язані зі стратегічними, тактичними та оперативними цілями кожної соціально-економічної системи, яка є iï частиною, тому досягнення стратегічних цілей кожної соціально-економічної системи у складі складної призведе до досягнення й їі цілей відповідно. Окрім того, вони повинні узгод- жуватися із цілями державного управління, оскільки такого роду системи, як, наприклад, паливно-енергетичний комплекс, підпорядковуються у функціонуванні не лише безпосередньому керівництву, а й системі вищого рівня - державі.

Спираючись на проведене нами дослідження, можна виділити такі завдання для системи економічної безпеки паливно-енергетичного комплексу:

- формування належної системи захисту для кожного підприємства, що входить до його складу, та iii підтримка протягом усіх етапів життєвого циклу;

- здійснення заходів щодо ідентифікації викликів, ризиків, загроз та небезпек;

- ефективне використання ресурсів кожного підприємства, що входить до його складу, під час забезпечення та гарантування економічної безпеки;

- постійне державне сприяння забезпеченню та гарантуванню безпеки;

- застосування профілактичних заходів щодо підтримання необхідного рівня економічної безпеки.

Жодне наукове пізнання не може обійтися без формування системи принципів, функцій.

Принципи системи економічної безпеки такої окремо взятої соціально-економічної системи, як підприємство, мають свої особливості, й їхня кількість постійно змінюється в процесі появи нових наукових досліджень. Переважна більшість провідних вітчизняних науковців [1-6] у сфері безпекознавства погоджується 3 такими принципами: системності (усі дії повинні бути узгоджені між собою за всіма напрямами діяльності, враховуються під час гарантування безпеки системні властивості); законності (усі дії щодо забезпечення та гарантування економічної безпеки повинні проводиться виключно в рамках чинного законодавства); безперервності (процес забезпечення та гарантування економічної безпеки повинен нести безперервний характер і потребувати постійного контролю); економічної доцільності (урахування своїх ресурсних можливостей і контроль над недопущенням перевищення витрат); плановості 
(обов'язкове планування превентивних та реактивних дій); своєчасності (усі заходи щодо забезпечення та гарантування економічної безпеки повинні бути своєчасними і відповідати поточній ситуації); взаємодії (під час забезпечення економічної безпеки повинні існувати взаємодія й координація між усіма підрозділами та ланками управління на підприємстві).

Ми вважаємо, що представлені вище принципи системи економічної безпеки слід застосовувати і для кожного підприємства у складі паливно-енергетичного комплексу (ПЕК), але, крім того, слід урахувати спеціальні принципи (рис. 1).
Ураховуючи той факт, що кожна соціально-економічна система, яка входить до складу даного комплексу, повинна дотримуватися певного переліку принципів, необхідно викреслити і спеціальні принципи, дотримання яких із боку держави й інших власників призведе до забезпечення економічної безпеки цілого комплексу. Такими принципами $є$ :

1. Принцип централізованого керівництва. Попри той факт, що кожне підприємство, що входить до складу паливно-енергетичного комплексу, має своє керівництво, для такої складної соціально-економічної системи повинна існувати вища ланка

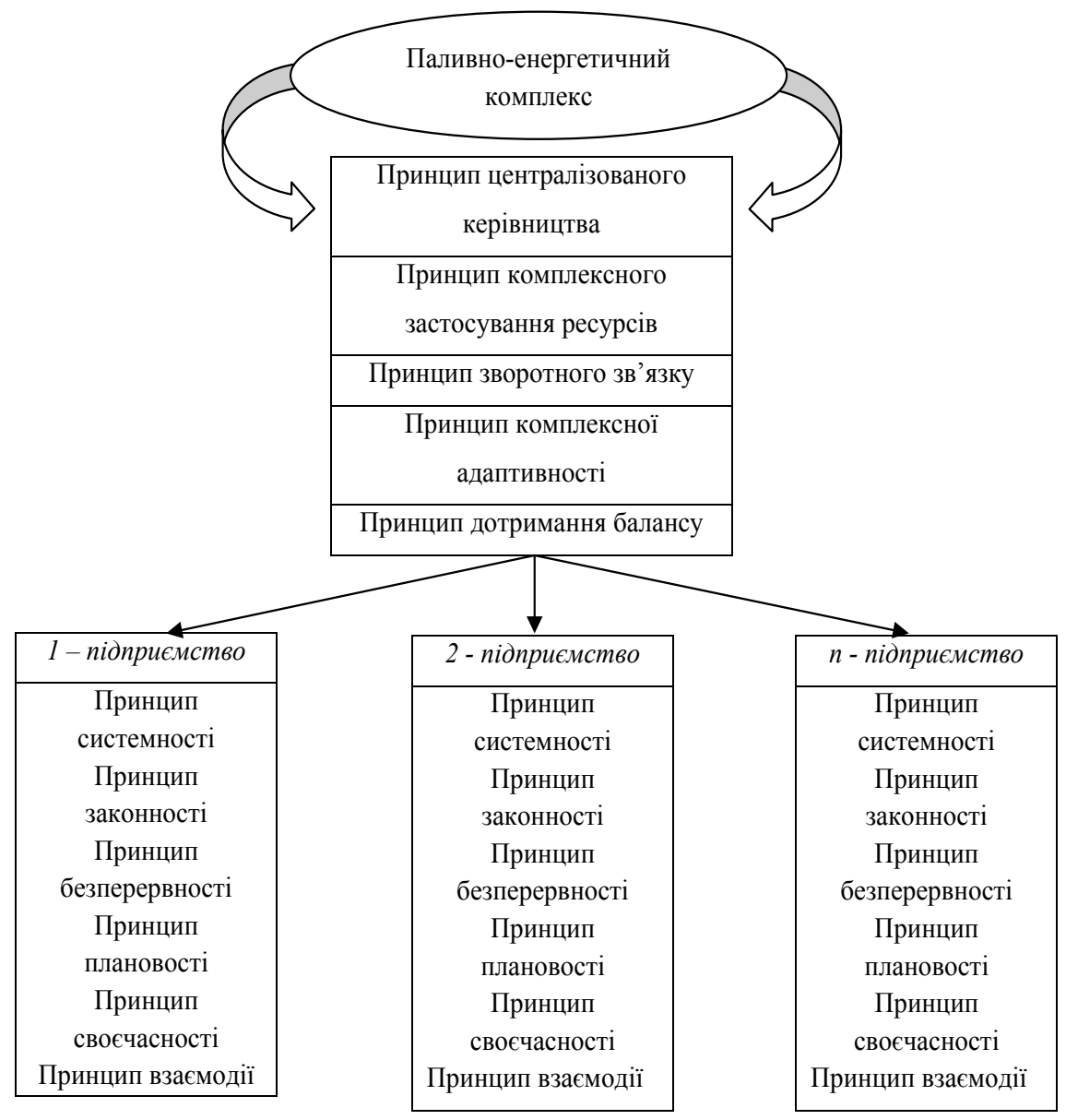

Рис. 1. Основні принципи системи економічної безпеки паливно-енергетичного комплексу 
Таблиця 1

Основні функції системи економічної безпеки складної соціально-економічної системи

\begin{tabular}{|l|l|}
\hline \multicolumn{1}{|c|}{ Функції } & \multicolumn{1}{c|}{ Характеристика } \\
\hline $\begin{array}{l}\text { Функція державного } \\
\text { контролю }\end{array}$ & $\begin{array}{l}\text { Постійна державна підтримка та формування сили зовнішніх зв'язків через } \\
\text { законодавство }\end{array}$ \\
\hline Захисна функція & $\begin{array}{l}\text { Гарантування захисту відбувається на кожному підприємстві, що є частиною } \\
\text { складної системи }\end{array}$ \\
\hline Контролююча функція & $\begin{array}{l}\text { Полягає у проведенні постійного порівняння фактичних і запланованих } \\
\text { станів складної системи }\end{array}$ \\
\hline $\begin{array}{l}\text { Навчально-мотиваційна } \\
\text { функція }\end{array}$ & $\begin{array}{l}\text { Для поліпшення та ефективного виконання поставлених завдань увесь } \\
\text { персонал, що задіяний у процесі забезпечення економічної безпеки, повинен } \\
\text { постійно поліпшувати свої навички і бути належно мотивованим }\end{array}$ \\
\hline $\begin{array}{l}\text { Обліково-аналітична } \\
\text { функція }\end{array}$ & $\begin{array}{l}\text { Процес забезпечення та гарантування економічної безпеки для такого типу } \\
\text { систем неможливий без комплексної обліково-аналітичної системи }\end{array}$ \\
\hline $\begin{array}{l}\text { Функція виявлення та } \\
\text { попередження загроз і } \\
\text { небезпек }\end{array}$ & $\begin{array}{l}\text { Дана функція передбачає, що керівництво усієї складної системи та кожної } \\
\text { системи, що входить до їі складу, повинно постійно здійснювати заходи } \\
\text { щодо виявлення та попередження будь-яких загроз і небезпек }\end{array}$ \\
\hline Наслідкова функція & $\begin{array}{l}\text { Означає, що керівники підприємств, що входять до складу складної системи, } \\
\text { повинні бути готові ліквідувати можливі наслідки нанесеної шкоди. } \\
\text { Держава ж повинна здійснювати заходи, спрямовані на ліквідацію наслідків } \\
\text { у зовнішньому середовищі функціонування системи }\end{array}$ \\
\hline
\end{tabular}

керівництва, яка забезпечує безпеку цілого комплексу.

2. Принцип комплексного застосування ресурсів. Ураховуючи участь держави в забезпеченні та гарантуванні економічної безпеки, вкрай важливим є ефективне та комплексне використання наявних ресурсів не лише на кожному підприємстві окремо, а й комплексу у цілому.

3. Принцип зворотного зв'язку. Не лише 3 вищої ланки керівництва повинна надходити інформації, а й навпаки. Кожне підприємство, що є частиною даного комплексу, повинно надавати відповідно інформацію про можливі загрози та небезпеки.

4. Принцип комплексної адаптивності. Вища ланка керівництва повинна здійснювати заходи щодо забезпечення максимальної гнучкості комплексу перед зовнішніми та внутрішніми загрозами.

5. Принцип дотримання балансу. Під час здійснення своєї діяльності та гарантування економічної безпеки завжди потрібно дотримуватися необхідного балансу життєво важливих інтересів особи, суспільства, держави, юридичних осіб, що входять до комплексу.
Що стосується основних функцій системи економічної безпеки складної соціально-економічної системи, то до їхнього складу необхідно віднести функції, що безпосередньо пов'язані з державним управлінням, яке відіграє не останню роль у розвитку та гарантуванні безпеки даного типу систем (табл. 1).

Особливістю системи економічної безпеки окремо взятого підприємства $є$ передусім безпосередньо завдання саме власника. Для складної соціально-економічної системи все по-іншому, оскільки вона характеризується щільними зв'язками між суб'єктами господарювання (незалежно від форм власності) і впливає на розвиток національної економіки. Поєднання зусиль власників і держави, що виходить за рамки просто створення сприятливого підприємницького клімату, визначається стратегічними орієнтирами всієї держави. У такому разі формування системи економічної безпеки складної соціально-економічної системи потребує іншого підходу, в якому враховується сила внутрішніх та зовнішніх зв'язків.

Висновки. За 27 років існування нашої держави менеджмент у таких складних соціально-економічних системах, як паливно- 
енергетичний комплекс, практично не змінився. Досі зберігається вертикальний державний контроль, що, з одного боку свідчить про високий рівень контролю, але 3 іншого - відсутній будь-який розвиток через відсутність застосування нових методів управління.

Економічна безпека в умовах складних соціально-економічних систем потребує створення такої системи, що дасть змогу узгодити інтереси не лише всередині даної складної системи, а й із вищим рівнем, тобто державою. Якщо це розглядати в розрізі такого типу складної системи, як паливно-енергетичний комплекс, то на перший план повинно виходити не лише досягнення економічних інтересів, а й соціальних та екологічних, ураховуючи специфіку діяльності.

\section{Список літератури:}

1. Копитко М.І. Комплексне забезпечення економічної безпеки підприємств : дис. ... д.е.н. : 21.04.02 ; Університет економіки і права «КРОК»».. Київ, 2015. 478 с.

2. Іванюта Т.М., Заїчковський А.О. Економічна безпека підприємства : навчальний посібник. Київ : Центр учбової літератури, 2009. 256 с.

3. Франчук В.I. Особливості організації системи економічної безпеки вітчизняних акціонерних товариств в умовах трансформаційної економіки : монографія. Львів: Львівський державний університет внутрішніх справ, 2010. 440 с.

4. Живко 3.Б. Економічна безпека підприємства: сутність, механізм забезпечення та управління : монографія. Львів: Львівський державний університет внутрішніх справ, 2012. 260 с.

5. Троц І.В. Забезпечення економічної безпеки на підприємстві з метою попередження банкрутства. Вісник Житомирського держсавного технологічного університету. Економічні науки. 2012. № 1(59). Ч. 2. С. 223-227.

6. Теоретико-методичні засади формування організаційного забезпечення управління економічною безпекою машинобудівного підприємства : монографія / О.В. Халіна та ін. Львів : Укр. акад. друкарства, 2016. 220 с.

\section{References:}

1. Kopytko M.I. (2015) Kompleksne zabezpechennya ekonomichnoyi bezpeky pidpryemstv [Comprehensive provision of economic security of enterprises] // dys. na zd. nauk. st. d.e.n. za specz.21.04.02. Vyshhyj navchalnyj zaklad «Universytet ekonomiky i prava «KROK»». $478 \mathrm{p}$.

2. Ivanyuta T. M., Zayichkovskyj A. O. (2009) Ekonomichna bezpeka pidpryemstva [Economic security of enterprises] : navch. posib. dlya stud. vyshh. navch. zakl. Kyiv : Centr uchbovoyi literatury, $256 \mathrm{p}$.

3. Franchuk V.I. (2010) Osoblyvosti organizaciyi systemy ekonomichnoyi bezpeky vitchyznyanyx akcionernyx tovarystv $\mathrm{v}$ umovax transformacijnoyi ekonomiky [Features of the organization of the system of economic security of domestic joint-stock companies in a transformational economy] : monografiya. Lviv: Lvivskyj derzhavnyj universytet vnutrishnix sprav, $440 \mathrm{p}$.

4. Zhyvko Z.B. (2012) Ekonomichna bezpeka pidpry'yemstva: sutnist', mexanizm zabezpechennya ta upravlinnya [Economic security of an enterprise: the essence, mechanism of maintenance and management] : monografiya. Lviv: Lvivskyj derzhavnyj universytet vnutrishnix sprav, $260 \mathrm{p}$.

5. Trocz I.V. (2012) Zabezpechennya ekonomichnoyi bezpeky na pidpryemstvi z metoyu poperedzhennya bankrutstva []. Visnyk Zhytomyrskogo derzhavnogo texnologichnogo universytetu [Ensuring economic security at the enterprise in order to prevent bankruptcy]. Ekonomichni nauky, № 1 (59). Ch.2, pp.223-227.

6. Khalina O.V., Shtangret A.M., Suhomlyn L.Ye., Melnykov O.V. (2016) Teoretykometodychni zasady formuvannya organizacijnogo zabezpechennya upravlinnya ekonomichnoyu bezpekoyu mashy'nobudivnogo pidpryemstva [Theoretical and methodical principles of forming the organizational support for managing the economic security of the machine-building enterprise]: monogr. Lviv : Ukr. akad. drukarstva, 220 p. 